\title{
COMMENTS
}

\section{DEALERS COERCING MANUFACTURERS: A PROPOSAL FOR A UNILATERAL ANTITRUST OFFENSE}

\author{
Ned E. Barlas $\dagger$

\section{INTRODUCTION}

Suppose a widget manufacturer supplies two dealers in the same city. One of the dealers (the "full-price dealer") sells the widgets at the manufacturer's suggested retail price. The full-price dealer advertises extensively and hires an expert sales and service staff to help customers before and after their purchase. ${ }^{1}$ The other dealer (the "discounter") attracts customers by selling widgets at a discounted price. Consequently, the discounter employs only a minimal support staff.

After losing much of its business to the discounter, the full-price dealer complains to the manufacturer, claiming that the discounter has unfairly diverted business from it by taking a free ride ${ }^{2}$ on its advertis-

† B.A. 1985, Swarthmore College; J.D. Candidate 1990, University of Pennsylvania.

1 Assume that a widget is a fairly sophisticated durable good, such as a computer, stereo component, or car, the sale and service of which usually requires a knowledgeable support staff.

2 See R. Posner, Antitrust Law 149 (1976). In a seminal article, Professor Telser described this sort of free rider problem as follows:

Sales are diverted from the retailers who do provide the special services at the higher price to the retailers who do not provide the special services and offer to sell the product at the lower price. The mechanism is simple. A customer, because of the special services provided by one retailer, is persuaded to buy the product. But he purchases the product from another paying the latter a lower price. In this way the retailers who do not provide the special services get a free ride at the expense of those who have convinced consumers to buy the product.

Telser, Why Should Manufacturers Want Fair Trade?, 3 J.L. \& EcoN. 86, 91 (1960). For further discussion of the free rider problem, see Monsanto Co. v. SprayRite Serv. Corp., 465 U.S. 752, 762-63 (1984); Continental T.V., Inc. v. GTE Sylvania Inc., 433 U.S. 36, 55 (1977); Shores, Vertical Price-Fixing and the Contract Conundrum: Beyond Monsanto, 54 FordhaM L. REv. 377, 400-03 (1985). Some commentators argue that free rider problems are of limited significance. See, e.g., Pitofsky, In Defense of Discounters: The No-Frills Case for a Per Se Rule Against Vertical Price Fixing, 71 GEo. L.J. 1487, 1493 (1983) ("Until the recent ideology about 'free riders' became fashionable, they were regarded as the very heart of a free market com- 
ing and pre-sale services. ${ }^{3}$ Eventually the full-price dealer issues an ultimatum to the manufacturer, stating that if the manufacturer does not terminate the discounter, the full-price dealer will stop selling the manufacturer's widgets. Thereafter the manufacturer terminates the discounter; in response, the discounter sues both parties under section 1 of the Sherman Act. ${ }^{4}$ Should the plaintiff discounter be awarded damages? If so, from whom: the manufacturer, the full-price dealer, or both?

Under recent Supreme Court precedent, ${ }^{5}$ the discounter cannot recover from either the manufacturer or the full-price dealer for a per $\mathrm{se}^{\mathrm{b}}$ section 1 violation unless it can prove that the full-price dealer agreed with the manufacturer, either "expressly or impliedly," to set prices at some level. ${ }^{7}$ Congress is currently considering legislation ${ }^{8}$ that would effectively overturn the recent precedent and reduce the evidentiary burden that a discontinued dealer would have to meet in order to prove that its termination violated section 1 . Under the pending legislation, the terminated discounter could make out a prima facie section 1 violation against both the manufacturer and full-price dealer if it could prove that the full-price dealer communicated with the manufacturer about the discounter, and that the discounter was terminated in response to this communication. ${ }^{9}$

This Comment argues that a manufacturer should not be subject to liability for the coerced termination of a discounter ${ }^{\mathbf{1 0}}$ and that the full-price dealer should, under certain circumstances, be held unilater-

petitive system."); Scherer, The Economics of Vertical Restraints, 52 ANTITRuST L.J. 687,694 (1983) ("Slowly, economists have come to realize that the free rider theory can carry only very limited weight."). But see Local Beauty Supply v. Lamaur, Inc., 787 F.2d 1197, 1202 n.2 (7th Cir. 1986) ("The validity and legality of manufacturers" prevention of free riding . . . has been settled by the Supreme Court in Monsanto . . . and Sylvania . . . ."); see also Popofsky and Bomse, From Sylvania to Monsanto: No Longer a "Free Ride", 30 ANTITRust Bull. 67, 93-94 (discussing the centrality of free rider concerns in fashioning antitrust rules).

${ }^{3}$ If the widget were a computer, pre-sale services might include designing a system to suit the customer's needs. If this were done prior to any contract between the customer and the retailer, the customer could use the designs to buy the system at a lower price from the discounter. For instance, in Business Elecs. Corp. v. Sharp Elecs. Corp., 108 S. Ct. 1515 (1988), the defendant manufacturer alleged that plaintiff, a terminated discounter, engaged in just this type of free riding. See Brief for Respondent Sharp Electronics Corp. at 4-5, Business Elecs. Corp. v. Sharp Elecs. Corp., 108 S. Ct. 1515 (1988) (No. 85-1910) [hereinafter Sharp's Brief].

- See infra note 12 and accompanying text.

- See Business Elecs., 108 S. Ct. at 1515; Monsanto, 465 U.S. at 752.

- See infra notes 15-17 and accompanying text.

7 Business Elecs., 108 S. Ct. at 1518.

8 See infra notes 53-59 and accompanying text.

- See infra notes 54-55.

${ }^{10}$ As a preliminary matter, it is interesting to consider the source of the com- 
ally liable for its coercion. When a coerced manufacturer decides to terminate a discounter, it is making a rational business decision about which of two dealers it would rather have distribute its goods. By contrast, the full-price dealer may be acting anticompetitively when presenting the manufacturer with the ultimatum. Whether or not it acts anticompetitively depends on its economic motives for coercing. If the full-price dealer delivers the ultimatum in order to improve an already profitable relationship at the expense of the discounter, then the coercion is anticompetitive; on the other hand, if the full-price dealer is not making sufficient profit to continue dealing in the manufacturer's goods, then the coercion may simply be a way for the full-price dealer to inform the manufacturer that the relationship cannot continue as long as the discounter continues to cut into its market. The latter type of coercion should not be proscribed. ${ }^{11}$ Under section 1 the requirement of concerted action implies that the manufacturer and the fullprice dealer are either both or neither liable. This Comment proposes an alternative framework to section 1 for considering coerced terminations. Instead of viewing the termination as the restraint on competition, the unilateral act of coercion is viewed as the restraint.

This Comment is divided into four parts. Part I presents the antitrust principles essential to an understanding of the discounter termination problem. Part II discusses the treatment of coerced terminations under section 1. This discussion includes the judicial consideration of the problem, and the way the law would operate under the pending legislation. Part III examines the failings of the section 1 framework in considering coerced terminations. Part IV sets forth a proposal to hold the coercing dealer, but not the coerced manufacturer, liable under the appropriate circumstances.

plaining dealer's power to coerce.

The complainer's bargaining power relative to the manufacturer is . . . elusive. It need only be sufficient to persuade the reluctant manufacturer that he would lose less by terminating the plaintiff than by losing the patronage of the complainer and perhaps of other silent dealers who share the complainer's sentiments.

.. . [The] manufacturer does not wish to terminate the plaintiff dealer but does so to placate the complaining dealer, who would otherwise cease handling the product. This manufacturer would rather keep both dealers but, when forced to choose between them, concludes that terminating the plaintiff hurts him less (considering sales lost, transaction costs in finding and perhaps training a replacement, and any spillover effects upon his relations with other dealers) than losing the complainer's patronage.

7 P. Areeda, Antitrust Law, paras. 1457a-1457b, at 166-67 (1986 \& Supp. 1988).

11 See infra notes $91-99$ and accompanying text. 


\section{The Section 1 Framework}

\section{A. The Requirement of Concerted Action}

Section 1 of the Sherman Act states: "Every contract, combination in the form of trust or otherwise, or conspiracy, in restraint of trade or commerce among the several states, or with foreign nations is declared to be illegal. ${ }^{.12}$ For a vertical restraint ${ }^{13}$ to be in violation of section 1 , such as one imposed by a manufacturer on one or more of its dealers, it must meet the requirement of "concerted" action. For instance, the manufacturer is free to terminate one of its dealers unilaterally, ${ }^{14}$ but it is not free to do so in concert with its dealers without running the risk

\section{U.S.C. \& 1 (1982).}

${ }^{13}$ Horizontal restraints, by contrast, are imposed by members on one level of distribution on other members at that same level. Ernest Gellhorn describes the rationale for section 1 violations in the context of horizontal restraints as follows:

The assumptions underlying Section 1 are that the societal benefits from competition will be endangered if rivals are permitted to join together and to consolidate their market power. Competition is directly impaired by agreements to restrict output and raise prices above competitive levels.

E. Gel.i.horn, ANTItrust Law and Economics 153 (3d ed. 1986).

14 In United States v. Colgate \& Co., 250 U.S. 300 (1919), the Supreme Court stated that "[i]n the absence of any purpose to create or maintain a monopoly, the [Sherman] [A]ct does not restrict the long-recognized right of trader or manufacturer engaged in an entirely private business, freely to exercise his own independent discretion as to parties with whom he will deal." Id. at 307. This principle has come to be known as the Colgate doctrine.

Since Colgate, "[t]he general trend has been to narrow Colgate by expanding the meaning of the term 'combination' under $\S 1$ of the Sherman Act." Note, Antitrust: Business Electronics Corp. v. Sharp Electronics Corp.- A Better Rule for Vertical Restraints, But is it Legal?, 1987 B.Y.U. L. Rev. 1035, 1041 n.23; see also Baker, Interconnected Problems of Doctrine and Economics in the Section One Labyrinth: Is Sylvania A Way Out?, 67 VA. L. Rev. 1457, 1477-83 (1981) (noting the Court's shift away from Colgate towards a standard of economic effect under Dr. Miles Medical Co. v. John D. Park \& Sons Co., 220 U.S. 373 (1911)); Comment, The Colgate Doctrine: Its Past and Present, 12 Hous. L. Rev. 409, 414 (1975) (noting the limited effect given to the Colgate doctrine throughout the 1960's).

Though the Supreme Court has narrowed the Colgate doctrine, it has recently reaffirmed its vitality in Monsanto Co. v. Spray-Rite Serv. Corp., 465 U.S. 752, 761 (1984) ("A manufacturer of course generally has a right to deal, or refuse to deal, with whomever it likes, as long as it does so independently."). See also Russell Stover Candies, Inc. v. FTC, 718 F.2d 256, 260 (8th Cir. 1983) ("[A] 'simple refusal to [re]sell [sic] to customers who will not sell at prices suggested by the seller is permissible under the Sherman Act." ") (quoting United States v. Parke, Davis \& Co., 362 U.S. 29, 43 (1960)); H.L. Moore Drug Exch. v. Eli Lilly \& Co., 662 F.2d 935, 946 (2d Cir. 1981) ("[W]e need not consider whether Lilly's action was motivated by anticompetitive reasons, since a unilateral decision to terminate, no matter what the reason, does not constitute a violation of the antitrust laws."), cert. denied, 459 U.S. 880 (1982); Edward J. Sweeney \& Sons, Inc. v. Texaco, 637 F.2d 105, 110-17 (3d Cir. 1980) ("Unilateral action, no matter what its motivation, cannot violate $\S 1$."), cert. denied, 451 U.S. 911 (1981). 
of violating section 1 .

\section{B. The Rule of Reason and Per Se Violations}

The Supreme Court has "repeatedly recognized [that] the Sherman Act was intended to prohibit only unreasonable restraints of trade."15

Ordinarily, whether particular concerted action violates [section] 1 of the Sherman Act is determined through case-bycase application of the so-called rule of reason-that is, 'the factfinder weighs all of the circumstances of a case in deciding whether a restrictive practice should be prohibited as imposing an unreasonable restraint on competition. ${ }^{16}$

Other restraints have been held to be per se violations and are therefore not judged on a case-by-case basis. Per se violations are "agreements or practices which because of their pernicious effect on competition and lack of any redeeming virtue are conclusively presumed to be unreasonable and therefore illegal without elaborate inquiry as to the precise harm they have caused or the business excuse for their use."17

\section{G. Vertical Price and Non-Price Restraints}

If a coerced decision to terminate is considered concerted action for purposes of imposing liability under section 1, then a critical question

16 NCAA v. Board of Regents of Univ. of Oklahoma, 468 U.S. 85, 98 (1984).

${ }_{16}$ Business Elecs. Corp. v. Sharp Elecs. Corp., 108 S. Ct. 1515, 1519 (1988) (quoting Continental T.V., Inc. v. GTE Sylvania Inc., 433 U.S. 36, 49 (1977)).

The rule of reason, first articulated in Standard Oil Co. v. United States, 221 U.S. 1 (1911), is considered the "traditional framework of analysis under $\$ 1$ of the Sherman Act." Sylvania, 433 U.S. at 49. In Chicago Bd. of Trade v. United States, 246 U.S. 231 (1918), Justice Brandeis, in now famous dictum, specified the factors to be considered under Standard Oil's rule of reason analysis:

[T] he court must ordinarily consider the facts peculiar to the business to which the restraint is applied; its condition before and after the restraint was imposed; the nature of the restraint and its effect, actual or probable. The history of the restraint, the evil believed to exist, the reason for adopting the particular remedy, the purpose or end sought to be attained, are all relevant facts. This is not because a good intention will save an otherwise objectionable regulation or the reverse; but because knowledge of intent may help the court to interpret facts and to predict consequences.

Id. at 238.

${ }_{17}$ Northern Pac. Ry. v. United States, 356 U.S. 1, 5 (1958). Per se illegality applies only to practices that lack any redeeming virtue and are "naked restraints of trade with no purpose except stifling of competition." White Motor Co. v. United States, 372 U.S. 253, 263 (1963). 
is whether such termination should be considered a vertical price or vertical non-price restraint. As will be discussed below, vertical price restraints are per se section 1 violations, whereas vertical non-price restraints are generally judged under the rule of reason.

\section{Vertical Price Restraints}

The Supreme Court first pronounced vertical price restraints, otherwise known as resale price maintenance (RPM), a per se section 1 violation in Dr. Miles Medical Co. v. John D. Park $\mathcal{G}$ Sons Co. ${ }^{18}$ RPM occurs when a manufacturer expressly or impliedly agrees with its distributors to set a price at which its goods will be resold. For instance, a manufacturer could make an overt agreement with its dealers for them to maintain their prices at some level. Alternatively, vertical price restraints may be found if the manufacturer extracts adherence to its designated resale prices through threats of dealer termination. ${ }^{19}$

18220 U.S. 373 (1911); see also Sylvania, 433 U.S. at 51 n.18 ("The per se illegality of price restrictions has been established firmly for many years . . . ."); Albrecht v. Herald Co., 390 U.S. 145, 151-52 (1968) (stating that it is a long accepted rule that concerted resale price fixing is a per se $\S 1$ violation); Schwegmann Bros. v. Calvert Distillers Corp., 341 U.S. 384, 386 (1951) (holding that fixing minimum prices is a per se violation of the Sherman Act); United States v. Bausch \& Lomb Optical Co., 321 U.S. 707, 720 (1944) (holding that price fixing is per se illegal regardless of its reasonableness); Straus v. Victor Talking Mach. Co., 243 U.S. 490, 501 (1917) (holding unlawful an attempt by a manufacturer of a patented machine to control the resale price through restrictive licensing procedures). But see Baxter, The Viability of Vertical Restraints Doctrine, 75 CALIF. L. Rev. 933, 933-34 (1987) (describing the conclusion reached in Dr. Miles as "demonstrably erroneous").

19 See, e.g., Perma Life Mufflers v. International Parts Corp., 392 U.S. 134, 142 (1968) ("[E]ach petitioner can clearly charge a combination between [the franchiser] and himself as of the day he unwillingly complied with restrictive franchise agreements, . . . or between [the franchiser] and other franchise dealers, whose acquiescence in [the franchiser's] firmly enforced restraints was induced by the 'communicated damage of termination." " (citation omitted)); Albrecht, 390 U.S. at 149 ("The combination with retailers arose because their acquiescence in the suggested prices was secured by threats of termination . . . ."); Simpson v. Union Oil Co., 377 U.S. 13, 17 (1964) ("We made clear in [Parke, Davis] that a supplier may not use coercion on its retail outlets to achieve resale price maintenance. We reiterate that view, adding that it matters not what the coercive device is." (citation omitted)); United States v. Parke, Davis \& Co., 362 U.S. 29, 46-47 (1960) (a manufacturer who coerces dealers to maintain prices is "the organizer of a price-maintenance combination or conspiracy in violation of the Sherman Act"); Black Gold, Ltd. v. Rockwool Indus., 729 F.2d 676, 686 (10th Cir.) ("IA] plaintiff who contends a seller has unlawfully used a refusal to deal as a means of enforcing an anticompetitive practice . . may establish the requisite combination or conspiracy ...."), affd with addendum, 732 F.2d 779, (10th Cir.), cert. denied, 469 U.S. 854 (1984); Yentsch v. Texaco, 630 F.2d 46, 54-55 (2d Cir. 1980) (unlawful agreement found from threats of termination and then actual termination); Arnott $v$. American Oil Co., 609 F.2d 873, 884-85 (8th Cir. 1979) (holding that a threat not to renew an annual lease if suggested price guidelines were not followed was coercion 


\section{Vertical Non-Price Restraints}

In Continental T.V., Inc. v. GTE Sylvania Inc., ${ }^{20}$ the Supreme Court announced a rule of reason analysis for evaluating non-price vertical restrictions. ${ }^{21} \mathrm{~A}$ central aspect of the Court's holding was its recognition that " $[t]$ he market impact of vertical restrictions is complex because of their potential for a simultaneous reduction of intrabrand competition and stimulation of interbrand competition." 22 The Court found this to be the case as "[v]ertical restrictions promote interbrand competition by allowing the manufacturer to achieve certain efficiencies in the distribution of his products. ${ }^{223}$ The Sylvania decision, however, noted that under some circumstances a per se rule involving vertical non-price restrictions might be appropriate: "[W]e do not foreclose the possibility that particular applications of vertical restrictions might justify per se prohibition . . . But we do make clear that departure from the rule-of-reason standard must be based upon demonstrable economic effect rather than . . . upon formalistic line drawing."24

under the antitrust laws), cert denied, 446 U.S. 918 (1980); R \& G Affiliates, Inc. v. Knoll Int'l, Inc., 587 F. Supp. 1395, 1399 (S.D.N.Y. 1984) (holding that concerted action can be "shown by "proof of . . . the securing of actual adherence to [the [pricing] policy at issue] by means beyond mere refusal to deal" " (quoting Yentsch, 630 F.2d at 52)).

20433 U.S. 36 (1977).

21 This was actually a return to the rule of reason analysis after a ten year departure from it beginning with United States v. Arnold, Schwinn \& Co., 388 U.S. 365 (1967). See Sylvania, 433 U.S. at 59 ("[T]he appropriate decision is to return to the rule of reason that governed vertical restrictions prior to Schwinn."). In Schwinn, the Court had deemed territorial restrictions to be per se illegal. See Schwinn, 338 U.S. at 382.

${ }^{22}$ Sylvania, 433 U.S. at 51 . The Court stated that interbrand competition is of greater concern than intrabrand competition to the antitrust laws: "Interbrand competition is the competition among the manufacturers of the same generic product . . . and is the primary concern of antitrust law. . . . In contrast, intrabrand competition is the competition between the distributors-wholesale or retail-of the product of a particular manufacturer." Id, at 52 n.19.

${ }^{23}$ Id. at 54.

24 Id. at 58-59. Since Sylvania, however, courts have rejected arguments that conclude that territorial restrictions are per se unlawful. See, e.g., First Beverages, Inc. v. Royal Crown Cola Co., 612 F.2d 1164, 1169-70 (9th Cir.) (finding an exclusive territorial trademark licensing system not to be per se illegal), cert. denied, 447 U.S. 924 (1980); Del Rio Distrib., Inc. v. Adolph Coors Co., 589 F.2d 176, 179 (5th Cir.) (upholding the district court's finding that territorial restrictions are not per se illegal), cert. denied, 444 U.S. 840 (1979); General Beverage Sales Co. v. East-Side Winery, 568 F.2d 1147, 1153-54 (7th Cir. 1978) (refusing to find territorial restrictions imposed by wine and spirit supplier to be per se illegal); Eiberger v. Sony Corp., $459 \mathrm{~F}$. Supp. 1276, 1282 (S.D.N.Y. 1978) (finding a warranty program whose effect was to restrict territories not to be per se illegal), affd in part, rev'd in part, 622 F.2d 1068 (2d Cir. 1980); see also Eastern Scientific Co. v. Wild Heerbrugg Instruments, Inc., 572 F.2d 883, 884-85 (1st Gir.) (holding territorial restrictions imposed by scientific instrument distributor not per se illegal although emanating from resale price restric- 


\section{The Treatment of Coerced Terminations Under SECTION 1}

\section{A. The Judicial Approach}

Courts have disagreed about how to treat terminations of discounters by coerced manufacturers under section 1 . Some courts have concluded that such a termination is pursuant to a price fixing agreement and therefore a per se violation of section $1 ;^{25}$ other courts have found such a termination to be a non-price based restriction and therefore subject to the rule of reason; $;^{26}$ still other courts have found no concerted action and have held that the manufacturer's decision to ter-

tions), cert. denied, 439 U.S. 833 (1978).

25 See, e.g., Malley-Duff \& Assoc. v. Crown Life Ins. Co., 734 F.2d 133, 140-41 (3d Cir.) (stating that a vertical agreement can have the purpose of price fixing, in which case the per se rule is applied), cert. denied sub nom. Agency Holding Corp. v. Malley-Duff \& Assoc., 469 U.S. 1072 (1984); Zidell Explorations, Inc. v. Conval Int'l, Ltd., 719 F.2d 1465, 1469 (9th Cir. 1983) ("[I]f a manufacturer deliberately withdraws its product from a price-cutting distributor at the request of a competing distributor as part of a conspiracy to protect the requesting distributor from price competition, the manufacturer has committed a per se violation of the antitrust laws." (citing Cernuto, Inc. v. United Cabinet Corp., 595 F.2d 164, 170 (3d Cir. 1979))); JBL Enters. v. Jhirmack Enters., 698 F.2d 1011, 1015 (9th Cir.) (noting that vertical agreements can have the purpose of fixing prices which is a per se violation of the Sherman Act), cert. denied, 464 U.S. 829 (1983); Cernuto, 595 F.2d at 168 (seller's refusal to supply discounting retailer because of pressure from another retailer is potential per se violation particularly when pressuring retailer's motivation is price fixing).

The Supreme Court took note of these cases in Business Elecs. Corp. v. Sharp Elecs. Corp., 108 S. Ct. 1515, 1517 n.1 (1988), and held that the termination would be assessed under the rule of reason unless there was an agreement on price or price levels between the manufacturer and the non-terminated dealer. See id. at 1525.

${ }^{26}$ See, e.g., Business Elecs., 108 S. Ct. at 1520 (concluding that an agreement to terminate a discounter in absence of agreement to set prices is a non-price vertical restraint and therefore subject to the rule of reason); McCabe's Furniture, Inc. v. LaZ-Boy Chair Co., 798 F.2d 323, 329 (8th Cir. 1986) ("[F]or a terminated dealer to prevail on its per se claim, the evidence must be sufficient for the jury to determine not merely that the manufacturer and non terminated dealer conspired, but that they conspired to maintain resale prices."), cert. denied, 108 S. Ct. 1728 (1988); Morrison v. Murray Biscuit Co., 797 F.2d 1430, 1440 (7th Cir. 1986) (holding that a termination for non compliance of an agreement without price fixing is not a per se violation notwithstanding the fact that the suppliers learned of the non compliance through a competing dealer whose sole purpose was to protect its own prices); Westman Comm'n Co. v. Hobart Int'l, Inc., 796 F.2d 1216, 1224 (10th Cir. 1986) (manufacturer's concerted refusal to deal with certain distributors is not per se illegal since there was not "the slightest hint of price maintenance or price fixing"), cert. denied 108 S. Ct. 1728 (1988); Hennessy Indus., Inc. v. FMC Corp., 779 F.2d 402, 403-04 (7th Cir. 1985) (no per se violation where manufacturer refuses, at behest of a distributor, to deal with a competitor on comparable terms); Products Liab. Ins. Agency, Inc. v. Crum \& Forster Ins. Cos., 682 F.2d 660, 663 (7th Cir. 1982) ("[I]n the absence of any evidence of intent to raise prices... an agreement whereby a supplier of some good or service refuses, at the behest of one of his distributors, to deal with a competitor of that distributor is not illegal per se."). 
minate in response to coercive conduct is unilateral and therefore legal. ${ }^{27}$ The Supreme Court's recent Monsanto and Business Electronics decisions have narrowed the disparity in approaches taken by courts when deciding a dealer termination case under section 1. Monsanto established the evidentiary burden that a plaintiff must meet in order to prove concerted action. Business Electronics defined what actions a plaintiff must prove in order to establish a per se section 1 violation.

\section{Monsanto Company v. Spray-Rite Service Corporation ${ }^{28}$}

In Monsanto the Supreme Court addressed "the standard of proof required to find a vertical price-fixing conspiracy in violation of [section 1] of the Sherman Act." ${ }^{29}$ The Monsanto Company, a manufacturer of chemical herbicides, stopped supplying the Spray-Rite Service Corporation, a discount wholesale distributor of its agricultural chemicals, subsequent to complaints from some of Spray-Rite's rival dealers. Spray-Rite sued under section 1, "alleg[ing] that Monsanto and some of its distributors conspired to fix the resale prices of Monsanto herbicides," and in furtherance of this conspiracy-"sterminated Spray-Rite's distributorship, adopted compensation programs and shipping policies, and encouraged distributors to boycott Spray-Rite . . . ."30 Monsanto denied the conspiracy allegations and asserted that "Spray-Rite's distributorship had been terminated because of its failure to hire trained salesmen and promote sales to dealers adequately."31 After the District Court instructed the jury that Monsanto's conduct was per se unlawful if it "was in furtherance of a conspiracy to fix prices," the jury found that there had been such a conspiracy. ${ }^{32}$ The Seventh Circuit affirmed, holding that "there was sufficient evidence to satisfy Spray-Rite's burden of proving a conspiracy to set resale prices." 33

The Supreme Court, in a unanimous opinion ${ }^{34}$ by Justice Powell, affirmed the Seventh Circuit. Justice Powell discussed the sufficiency of

${ }^{27}$ See, e.g., Garment Dist., Inc. v. Belk Stores Servs., Inc., 799 F.2d 905, 908-09 (4th Cir. 1986) (stating that a plaintiff must show evidence of concerted action beyond complaints about a terminated dealer's prices), cert. denied, 108 S. Ct. 1728 (1988); National Marine Elec. Distribs., Inc. v. Raytheon Co., 778 F.2d 190, 192-93 (4th Cir. 1985) (holding that no agreement is found where the only evidence is dealer price complaints).

${ }_{28} 465$ U.S. 752 (1984).

29 Id. at 755.

${ }^{30} I d$. at 757 .

31 Id.

${ }^{32}$ See id. at 757-58.

${ }^{33}$ Id. at 758 (citing Spray-Rite Serv. Corp. v. Monsanto Co. 684 F.2d 1226 (7th

Cir. 1982).

${ }^{34}$ Justice White did not participate. 
evidence necessary to find that a discounter termination was pursuant to concerted action:

Permitting an agreement to be inferred merely from the existence of complaints, or even from the fact that termination came about 'in response to' complaints, could deter or penalize perfectly legitimate conduct.

.. .[S]omething more than evidence of complaints is needed. There must be evidence that tends to exclude the possibility that the manufacturer and non-terminated distributors were acting independently. . . . [T]he antitrust plaintiff should present direct or circumstantial evidence that reasonably tends to prove that the manufacturer and others 'had a conscious commitment to a common scheme designed to achieve an unlawful objective. ${ }^{35}$

The evidentiary standard established in Monsanto made the plaintiff's burden of proof in a coerced termination case more confusing and more onerous. ${ }^{36}$

\section{Business Electronics Corporation v. Sharp Electronics Corporation $^{37}$}

The Court's holding in Monsanto helped foster a division in the lower courts about whether to treat a discounter's termination, once concerted action was found, as a vertical price or non-price restraint. ${ }^{38}$

s5 Monsanto, 465 U.S. at 763-64 (quoting Edward J. Sweeney \& Sons, Inc. v. Texaco, Inc., 637 F.2d 105, 111 (3d Cir. 1980), cert denied, 451 U.S. 911 (1981)); see also Monsanto, 465 U.S. at $764 \mathrm{n} .9$ (" $[\mathrm{A}]$ meeting of the minds' or 'a common scheme" "requires "more than a showing that the distributor conformed to the suggested price . . . evidence must be presented both that the distributor communicated its acquiescence or agreement, and that this was sought by the manufacturer.").

${ }^{36}$ The "common scheme" that Justice Powell had in mind was the alleged fixing of distributor prices orchestrated by Monsanto; witness his reference to the agreement "sought by the manufacturer." Id. (emphasis added). This evidentiary burden can be applied to discounter termination but would be difficult to satisfy: while a coerced discounter termination would be "in response to" coercion, it would be difficult to argue that the manufacturer had a conscious commitment to the dealer's scheme. See $7 \mathrm{P}$. AREEDA, supra note 10 , at para. 1458.

37108 S. Ct. 1515 (1988).

${ }^{38}$ Prior to the Monsanto decision, the Third and Ninth Circuits had both held that such a termination should be considered a vertical price restraint. See Zidell Explorations, Inc. v. Conval Int'l, Ltd., 719 F.2d 1465, 1470 (9th Cir. 1983); Cernuto, Inc. v. United Cabinet Corp., 595 F.2d 164, 170 (3d Cir. 1979). Subsequent to Monsanto, the Fifth, Seventh, Eighth, and Tenth Circuits disagreed. See McCabe's Furniture, Inc. v. La-Z-Boy Chair Co., 798 F.2d 323, 330 (8th Cir. 1986), cert. denied 108 S. C.t 1728 (1988); Morrison v. Murray Biscuit Co., 797 F.2d 1430, 1440 (7th Cir. 
Business Electronics resolved this dispute.

The facts in Business Electronics closely resemble those in the introductory example. ${ }^{39}$ In the late 1960's and early 1970's, Sharp sold business calculators in Houston, Texas through two distributors, Business Electronics and Hartwell. Hartwell engaged in costly advertising and customer services, and usually sold the calculators at Sharp's suggested retail price. Business Electronics' prices, on the other hand, were often below Sharp's suggested retail prices, and generally below Hartwell's retail prices. ${ }^{40}$ Hartwell complained to Sharp that Business Electronics was taking a free ride at Hartwell's expense. ${ }^{41}$ Eventually, Hartwell threatened that it would stop selling Sharp products if Business Electronics was not terminated. ${ }^{42}$ In response to this ultimatum, Sharp terminated its relationship with Business Electronics.

Though constrained by the Monsanto evidentiary standard, ${ }^{43}$ the district court deemed the evidence sufficient to send to the jury. The jury found that Sharp's decision to terminate its relationship with Business Electronics was not unilateral, but part of a concerted effort to terminate a price cutter, and was therefore a per se violation of section $1 .{ }^{44}$

1986); Westman Comm'n Co. v. Hobart Int'l, Inc., 796 F.2d 1216, 1223-24 (10th Cir. 1986), cert. denied, 108 S. Ct. 1728 (1988); Business Elecs. Corp. v. Sharp Elecs. Corp., 780 F.2d 1212, 1218 (5th Cir. 1986), affd, 108 S. Ct. 1515 (1988).

39 See supra notes $1-4$ and accompanying text.

10 See Business Elecs., 108 S. Ct. at 1518.

41 "[M]uch of the evidence in this case was conflicting-in particular, concerning whether petitioner was 'free riding' on Hartwell's provision of presale educational and promotional services by providing inadequate services itself . . .."Id.

12 See id. Neither side disputed the ultimatum. See Sharp's Brief, supra note 3, at 6; Brief of Petitioner Business Electronics Corp. at 5, Business Elecs. Corp. v. Sharp Elecs. Corp., 108 S. Ct. 1515 (1988) (No. 85-1910) [hereinafter Business Electronics' Brief].

43 See supra note 35 and accompanying text.

11 The jury was given the following instructions:

The Sherman Act is violated when a seller enters into an agreement or understanding with one of its dealers to terminate another dealer because of the other dealer's price cutting. Plaintiff contends that Sharp terminated Business Electronics in furtherance of Hartwell's desire to eliminate Business Electronics as a price-cutting rival.

If you find that there was an agreement between Sharp and Hartwell to terminate Business Electronics because of Business Electronics' price cutting, you should answer yes to Question Number 1.

A combination, agreement or understanding to terminate a dealer because of his price cutting unreasonably restrains trade and cannot be justified for any reason. Therefore, even though the combination, agreement or understanding may have been formed or engaged in . . . to eliminate any alleged evils of price cutting, it is still unlawful. . . .

If a dealer demands that a manufacturer terminate a price cutting dealer, and the manufacturer agrees to do so, the agreement is illegal if the 
The Fifth Circuit reversed and remanded, holding that the jury charge was erroneous, ${ }^{45}$ and that to find per se illegal an agreement between a manufacturer and a dealer to terminate a second dealer, the first dealer "must expressly or impliedly agree to set its prices at some level, though not a specific one. The distributor cannot retain complete freedom to set whatever price it chooses." ${ }^{46}$

The Supreme Court affirmed, holding that "a vertical restraint is not illegal per se unless it includes some agreement on price or price levels." 47 In his majority opinion ${ }^{48}$ Justice Scalia rejected the "proposition that vertical price agreements generally underlie agreements to terminate a price cutter." ${ }^{\prime 49}$ Justice Scalia also doubted the ability of juries to accurately determine a manufacturer's motives for terminating a dealer:

In the vast majority of cases, it will be extremely difficult for the manufacturer to convince a jury that its motivation [for terminating a discounter] was to insure adequate services, since price cutting and some measure of service cutting usually go hand in hand. Accordingly, a manufacturer that agrees to give one dealer an exclusive territory and terminates another dealer pursuant to that agreement, or even a manufacturer that agrees with one dealer to terminate another for failure to provide contractually-obligated services, exposes itself to the highly plausible claim that its real motivation was to terminate a price cutter. ${ }^{50}$

For example, a manufacturer's decision to terminate because the discounter did not provide adequate customer services might easily be mistaken by a jury to be a decision to terminate under pressure by a dealer because of its price cutting. The same evidence could be used to support either conclusion.

"[E]ven vertical restraints that do not result in dealer termination, such as ... the requirement that certain services be provided, can be attacked as designed to allow existing dealers to charge higher

manufacturer's purpose is to eliminate the price cutting.

Business Elecs., 108 S. Ct. at 1518. 1986).

45 See Business Elecs. Corp. v. Sharp Elecs. Corp., 780 F.2d 1212, 1214 (5th Cir.

${ }^{46} I d$. at 1218.

47 Business Elecs., 108 S. Ct. at 1525. decision.

48 Justices White and Stevens dissented. Justice Kennedy did not take part in the

49 Business Elecs., 108 S. Ct. at 1523.

so Id. at 1521 . 
prices." This is because "all vertical restraints . . . have the potential to allow dealers to increase 'prices' and can be characterized as intended to achieve just that." 52

The Supreme Court's resolution is not so much an evidentiary matter as it is a conceptual matter. The Court defined what actions by the defendants, if proven by the terminated discounter, will be considered a per se section 1 violation. The Court held that a discounter termination at the behest of a rival dealer will not be considered a section 1 violation unless there is an agreement on prices or price levels.

\section{B. The Pending Legislation}

The Supreme Court's decisions in Monsanto and Business Electronics may soon be overturned if legislation pending in Congress is passed. The House of Representatives recently passed the Freedom From Vertical Price Fixing Act of 1987 [hereinafter "House Act"]. ${ }^{\text {ss }}$ The House Act was intended "[t]o establish evidentiary standards for Federal civil antitrust claims based on resale price fixing." 54 In the Senate, a similar bill, The Retail Competition Enforcement Act of 1987, ,5 [hereinafter "Senate Bill"] is being considered.

s1 Id.

${ }^{32}$ Id. at 1521-22.

s3 H.R. 585, 100th Cong., 1st Sess. (1987). The House Bill was passed on November 9, 1987.

${ }^{34}$ Id. at preamble. The Act states in pertinent part:

Section 2. Evidentiary Standards In Federal Givil AN'Ttrust Actions Relating To Price Fixing.

(a) In a civil action based on a claim arising under section 1 or 3 of the Sherman Act (15 U.S.C. 1,3) and alleging a contract, combination, or conspiracy to set, change, or maintain prices, including a minimum or maximum price, evidence that a person who sells a good or service to the claimant for resale-

(1) received from a competitor of the claimant a communication regarding price competition by the claimant in the resale of such good or service, and

(2) in response to such communication terminated the claimant as a buyer of such good or service for resale, or refused to supply to the claimant some or all of such goods or services requested by the claimant, shall be sufficient to raise the inference that such person [the manufacturer] and such competitor [the full-price dealer] engaged in concerted action to set, change, or maintain prices, including a minimum or maximum price, for such good or service in violation of such section.

Id. at $1-2$.

${ }_{85}$ S. 430, 100th Cong., 1st Sess. (1987). The Bill states in pertinent part:

Secrion 2. The Sherman Act is amended by redesignating section 8 and any references to section 8 as section 9 and by inserting between section 7 and section 9, as herein redesignated, the following new section:

"Sec. 8. (a) In any civil action based on section 1 or 3 of this Act, ... which alleges a contract, combination or conspiracy to set, change, or 
Both bills are designed to overturn Monsanto, in that they provide that a plaintiff discounter satisfies its evidentiary burden if, in a civil action alleging "a contract, combination, or conspiracy to set, change, or maintain prices," turer received an ultimatum from the full-price dealer "in response to" which or "because of" which it terminated the discounter. ${ }^{57}$ The proponents of the legislation ${ }^{58}$ believe that Monsanto broke from the Supreme Court's traditional view that vertical price fixing is per se illegal, and as a result of the "ambiguous language in Monsanto, [some courts] have inappropriately dismissed cases or imposed incorrect standards of proof in vertical price-fixing cases." 50

maintain prices, if there is sufficient evidence from which a trier of fact could reasonably conclude that a person who sells a good or service to the claimant for resale

"(1) received from a competitor of the claimant an express or implied suggestion, request, or demand, including a threat to discontinue an existing business arrangement, that the seller take steps to curtail or eliminate price competition by claimant in the resale of such good or service, and

"(2) because of such suggestion, request, demand, or threat terminated the claimant as buyer of such good or service for resale or refused to supply to the claimant some or all of such goods or services requested by the claimant,

then the court shall permit the trier of fact to consider whether such person [the manufacturer] and such competitor [the full-price dealer] engaged in concerted action set, change, or maintain prices for such good or service in violation of such section.

Id.

${ }^{5 B}$ House Act $\S 2(a) ;$ Senate Bill § 8(a).

57 See P. Rodino, Freedom From Vertical Price Fixing Act of 1987, H.R. ReP. No. 421, 100th Cong., 1st Sess. 26 (1987) [hereinafter House REPORT]; R. Byrd, The Retail Competition Enforcement Act of 1987, S. Rep. No. 280, 100th Cong., 2d Sess. 6 (1988) [hereinafter SENATE REPORT]. The pending legislation would also render Business Elecs. moot, as it is an extension of Monsanto. See Bork, Keep Antitrust Pro-Consumer, ForTune, July 4, 1988, at 143, 144 ("Though the bill is presented as codifying existing law, it would in fact destroy the rule Business Electronics rested upon.").

Under the pending legislation, a coerced decision to terminate a discounter would be considered an agreed-to decision for purposes of imposing liability. See SENATE REPORT, supra, at 6 n. 3 ("Coercing a party into an illegal agreement does not exonerate the coerced party from civil liability.").

${ }^{58}$ The sponsors of H.R. 585 were Henry J. Hyde and Peter W. Rodino, Jr. See H.R. 585, 100th Cong., 1st Sess. 1 (1987).

S. 430 was introduced by Sens. Metzenbaum, Rudman, Simon, and Bradley on February 2, 1987. On August 6, 1987 the Senate Judiciary Committee approved an amendment to the bill in the nature of a substitute cosponsored by Sens. DeConcini, Grassley, Metzenbaum, and Leahy. See Senate ReporT, supra note 57, at 5.

so SENATE REPORT, supra note 57, at 4; House REPORT, supra note 57, at 2. 


\section{The Failings of Section 1}

Though the Supreme Court precedent and the pending legislation represent very different approaches to the illegality of coerced terminations, each is structured within the ambit of section 1 . Section 1 is targeted at concerted restraints of trade; therefore, when a coerced termination is held to be in violation of section 1 , the termination is deemed concerted action.

This part of the Comment argues that the coercing dealer, but not the coerced manufacturer, should be held liable for its coercion resulting in a rival dealer's termination. The manufacturer's choice to terminate a discounter in response to coercion is not anticompetitive; manufacturer liability is therefore unwarranted, and would be less efficient than holding the coercing dealer solely liable for its anticompetitive act of coercion. This analysis, however, would be outside of the scope of section 1 , because the restraint of trade would not be considered the product of a contract, combination, or conspiracy, but the result of a unilateral act-the full-price dealer's coercive conduct. ${ }^{60}$

\section{A. The Impropriety of Holding the Manufacturer Liable for a Coerced Termination Decision}

The pending legislation brings within its purview situations in which a manufacturer terminates a discounter because the manufacturer is coerced by a rival dealer into doing so. ${ }^{61}$ That this legislation should do so is unremarkable and should be expected because it follows previous holdings that coerced conduct is concerted conduct for purposes of section 1 actions. $^{62}$

Bo The termination could properly be characterized as concerted action in restraint of trade and hence come within the ambit of section 1, see 7 P. AREEDA, supra note 10 , para. $1457 \mathrm{~b}$, at 168 ("When the complainer threatens to abandon the manufacturer selling to discounters like the plaintiff, the manufacturer terminating the plaintiff implicitly 'accepts' the complainer's terms ....".). As will be argued, the full-price dealer acts anticompetitively when coercing the manufacturer, but the manufacturer does not act anticompetitively when deciding to terminate. Therefore, rather than viewing the coerced termination as the anticompetitive behavior (which has both anticompetitive and procompetitive elements), the coercion itself should be viewed as the actionable anticompetitive conduct.

${ }_{61}$ See Senate RePORT, supra note 57, at 6 n.3 ("Coercing a party into an illegal agreement does not exonerate the coerced party from civil liability.").

${ }_{62}$ For a comprehensive discussion of coerced manufacturer termination decisions, see 7 P. AREEDA, supra note 10, at para. 1457. Some courts have held coerced manufacturers liable in section 1 actions, and other courts have discussed their willingness to do so in dicta, see, e.g., Cernuto, Inc. v. United Cabinet Corp., 595 F.2d 164, 168 (3d Cir. 1979) ("When a marketing decision, although ostensibly taken by a manufacturer, is in fact the result of pressure from another customer.... the restraint becomes primarily horizontal in nature in that one customer is seeking to suppress its competi- 
Under Business Electronics, per se illegality would not logically apply to such terminations; Business Electronics requires for a finding of illegality that the full-price dealer not be free to set its prices as it chooses. ${ }^{63}$ If the manufacturer were truly coerced ${ }^{64}$ by the full-price dealer, then the full-price dealer would have no reason to relinquish its power to set its prices as it sees fit.

This part addresses the question whether holding the manufacturer liable for a coerced termination decision is proper and whether such liability adequately achieves the aim of the legislation. ${ }^{65}$ The true measure of whether manufacturer liability is appropriate should be the effect of such liability on competition.

\section{The Rationale for Coerced Manufacturer Liability}

The pending legislation is aimed at reducing discounter terminations resulting from price fixing agreements. ${ }^{68}$ The legislation recognizes a manufacturer's right to terminate a dealer unilaterally, but evidence that such a termination was in response to a communication about the discounter would be sufficient to raise an inference that the manufacturer's decision was part of a concerted design to set, change, or maintain prices. ${ }^{67}$

If the manufacturer can be held liable for a coerced decision, then

tion . . . ."); Galanetics Corp. v. Volkswagen, 532 F.2d 674, 682 (9th Cir.) ("An antitrust conspirator can be liable for damages even though he participates [in a vertical restraint] only under coercion."), cert. denied, 429 U.S. 940 (1976). But see Garment Dist., Inc. v. Belk Stores Servs., Inc., 799 F.2d 905, 909 (4th Cir. 1986) ("A manufacturer is not prohibited from avoiding the potential loss of many of its dealers because it acted in response to price complaints. . . . regardless of whether the complaints . . . constitute economic duress, coercion, and threats . . . ."); Packard Motor Car Co. v. Webster Motor Car Co., 243 F.2d 418, 422 (D.C. Cir.) (court refused to find antitrust violation on the part of a manufacturer who was coerced to terminate some of its dealers), cert. denied, 355 U.S. 822, (1957).

Some courts have held that coerced competitors in a horizontal relationship may be considered conspirators in section 1 violations. See, e.g., Duplan Corp. v. Deering Milliken, Inc., 594 F.2d 979, 982 (4th Cir. 1979) (per curiam) (holding corporate coconspirators liable for a scheme to restrain trade in textile industry, notwithstanding evidence of coercion), cert. denied sub nom. Atliers Roannaisde Constrs. Textiles v. Dunlap Corp., 444 U.S. 1015 (1980); Commonwealth Edison Co. v. Allis-Chalmers Mfg. Co., 245 F. Supp. 889, 892 (N.D. Ill. 1965) (horizontal price fixing participation not defensible on grounds of economic coercion).

${ }^{63}$ See 108 S. Ct. at 1523.

64 See supra note 10 .

6s The ostensible aim of the legislation is to reduce the incidence of dealer termination pursuant to a vertical price fixing agreement. at $2-3$.

Bo See SENATE REPORT, supra note 57, at 4-5; House REPORT, supra note 57,

67 See supra notes 54-55. 
apparently the law would prefer that the manufacturer act otherwise. ${ }^{68}$ According to the pending legislation, a manufacturer faced with dealer pressure to terminate a rival should not succumb to such pressure. ${ }^{69} \mathrm{By}$ turning its back on the full-price dealer's threats, however, the manufacturer would lose the full-price dealer's business (unless it was bluffing). When coerced, the manufacturer is faced with a choice between its two dealers. As will be discussed, the manufacturer's decision, free from the threat of potential liability, should be presumed to be the better choice $^{70}$ for consumers, and therefore the better choice for competition. ${ }^{71}$

The increased risk of litigation associated with succumbing to coercion would deter some manufacturers from choosing to terminate, thus resulting in fewer instances of future coercion. ${ }^{72}$ "Perhaps the object [of the legislation] is that, by creating more uncertainty as to outcomes, more plaintiffs will win through settlements or that more manufacturers will refrain from terminations . . . in the first place. That result is not clearly consistent with antitrust's consumer welfare objective."73 The effect of the increased risk of liability would be to make manufacturers less willing to succumb to pressure from coercing deal$\mathrm{ers}^{74}$ and to reduce the incidence of dealer coercion, both because dealers themselves will risk facing treble damages and because their chances for successfully coercing will be reduced due to their knowledge that the

68 See 6 P. AREEDA, supra note 10 para. 1408, at 39. ("'A]ction in accord with the other's desire should not be deemed a conspiracy as a prelude to imposing liability unless the court means to rule that the defendant should have acted otherwise.").

69 Unless the choice is truly unilateral, and even then the manufacturer may be deterred by the prospect of facing triple damages. See Edward J. Sweeney \& Sons, Inc. v. Texaco, Inc., 637 F.2d 105, 111 n.2 (3d Cir. 1980) ("To permit the inference of concerted action on the basis of receiving complaints alone and thus to expose the defendant to treble damage liability would both inhibit management's exercise of its independent business judgment and emasculate the terms of the statute."), cert. denied, 451 U.S, 911 (1981).

${ }^{70}$ It may be helpful to view the choice as a choice between two distributors rather than as a decision whether or not to terminate.

${ }^{71}$ See infra notes 76-87 and accompanying text. The manufacturer will choose the dealer which would maximize the manufacturer's profits by selling more of its widgets. The manufacturer would not necessarily choose on the basis of efficiency, but rather on size.

${ }^{72}$ This conclusion is based on elementary economic principles: as the price of something increases, the quantity demanded of that item typically decreases. The increased risk of litigation would increase the "price" (i.e. expected loss) of choosing to terminate; the increased price would then result in fewer manufacturer "choices" to terminate.

${ }_{73}$ Point/Counterpoint: Is Legislation Needed After Monsanto, 2 AnTITrust 33, 35 (Winter 1988) [hereinafter Point/Counterpoint] (Silberman, Counterpoint).

${ }^{74}$ See supra note 72. 


\section{The Effect of Coerced Manufacturer Liability on Competition}

The likelihood of a treble damage suit under the pending legislation would have the effect of increasing the cost of a manufacturer's decision to terminate a dealer. ${ }^{76}$ Let us assume, for the sake of exposition, that the manufacturer were free to terminate, even if coerced, without running the risk of per se illegality. ${ }^{77}$ When faced with an ultimatum by the full-price dealer, the manufacturer is essentially placed in a new business situation, faced with new decisions. ${ }^{78}$ Since a manufacturer is presumed to impose vertical restrictions so as best to promote its interbrand competitiveness, ${ }^{79}$ it would choose the dealer who would maximize its interbrand competitiveness ${ }^{80}$ and thus sell more goods to consumers, ${ }^{81}$ maximizing consumer welfare given the

${ }^{75}$ See Point/Counterpoint, supra note 73, at 35 (Silberman, Counterpoint).

76 See supra note 72.

77 This is similar to the present law under Business Elecs., provided there is no agreement on price or price levels. See Business Elecs., $108 \mathrm{~S}$. Ct. at 1525. The rule of reason analysis is used.

${ }^{78}$ In Business Elecs., Sharp argued that its response to Hartwell's ultimatum was made from "an objective business standpoint." Sharp's Brief, supra note 3, at 6.

79 See Continental T.V., Inc., v. GTE Sylvania Inc., 433 U.S. 36, 54 (1977) ("Vertical Restrictions promote interbrand competition by allowing the manufacturer to achieve certain efficiencies in the distribution of his products."); Bork, The Rule of Reason and the Per Se Concept: Price Fixing and Market Division, 75 Yale L.J. 373,403 (1966) (stating that a manufacturer imposes vertical restraints because it believes the restraints will increase its net revenue by increasing distributive efficiency); see also Brief of The National Ass'n of Manufacturers as Amicus Curiae in Support of Respondent at 11-12, Business Elecs. Corp. v. Sharp Elecs. Corp., 108 S. Ct. 1515 (1988) (No. 85-1910) [hereinafter NAM Brief]:

It was only when Hartwell's "him or me" ultimatum was presented that Sharp was forced to choose between competing dealers on the basis of all factual and legal factors.

Those factors involved the essence of managing a business of any kind. They involved deciding which of two or more alternatives would result in the most competitive product marketing capabilities, considering quality, quantity, efficiency, and compatibility with a marketing program. Sharp exercised its business judgment, and whether it was successful was to be tested in the harshness of the fiercely competitive world of calculators.

Id.

80 See R. Bork, The Antitrust Paradox 297 (1978) ("Basic Economic theory tells us that the manufacturer who imposes [vertical] restraints cannot intend to restrict output and must . . . intend to create efficiency.").

81 This assumes that the manufacturer sells the widgets to both the discounter and the full-price dealer at the same price. To maximize its profits, the manufacturer would want to choose the dealer who would buy more widgets; this would be the dealer who would sell more widgets to consumers (i.e. would be better able to meet consumer demand).

The assumption that the manufacturer sells the widgets to both the discounter and 
constraints imposed by the full-price dealer.

The possibility of being liable for treble damages alters the manufacturer's decision making process. ${ }^{82}$ The manufacturer would not always choose the dealer it believes would sell more of its product. When determining its expected stream of profits from each of its distributors, the manufacturer would take into account the expected loss due to a potential antitrust suit arising from terminating the discounter ${ }^{83}$ The expected civil liability would lower its expected profits from choosing the full-price dealer over the discounter. If the manufacturer then chooses not to terminate the discounter, it would probably lose the business of the full-price dealer even though that dealer might be better for interbrand competition and hence better able to meet consumer demand.

Restricting the manufacturer's choice of dealers by way of legislation will thus sometimes lead to inefficient results by inducing the manufacturer to choose the poorer interbrand competitor. The goal of this legislation is not simply to make the prospect of terminating the discounter less attractive to the manufacturer, but to reduce the probability that the manufacturer would have to make such a choice initially.

The reasoning behind the legislation is logical, ${ }^{84}$ but the result is not as fair or efficient as it could be. ${ }^{85}$ It would be better to hold the full-price dealer, but not the manufacturer, liable for its coercive conduct. The risk taken by a full-price dealer when coercing would be greater, thus decreasing the probability that it would coerce. ${ }^{86}$ Structur-

the full-price dealer at the same price is consistent with the Robinson-Patman Act, 15 U.S.C. $\S 13$ (1982 \& Supp. IV 1986). The Robinson-Patman Act prohibits price discrimination in the sale of commodities of like grade and like quality where the effect of such discrimination would be to restrain competition. See id. § 13(a). For an overview of this provision of the Robinson-Patman Act, see generally Rill, McDermott \& MacAvoy, Price, Promotion and Service Discrimination in ANTITrust ADVISER $\S 4$, $\S 4.04-.11$ (C. Hills ed. 1985 \& Supp. 1987) (discussing the requirements of $\S 13(\mathrm{a})$ ); Vawter, Jurisdiction, Commerce and Exemptions; Sales, Commodities and Like Grade and Quality Requirements, 53 ANTITRUST L.J. 847, 848-62 (1985) (same).

${ }_{82}$ This is based on the economic analogy discussed supra note 72 .

B3 See NAM Brief, supra note 79, at 11. ("When one dealer complains to a manufacturer about another dealer's prices, alarms go off. American manufacturers are extremely sensitive to the state of the law regarding resale price maintenance, the risks of terminating dealers, and the vicissitudes of judges and juries.")

84 First, the pending legislation makes the choice to coerce more costly for the retailer and the choice to terminate more costly for the manufacturer. Second, retailers will then coerce less for two reasons: the retailers risk being party to a law suit; and the manufacturers will be less likely to succumb to the pressure. For those retailers whose threats were empty, the chances are greater that they will be called.

${ }^{85}$ See infra notes 100-07 and accompanying text for a fairer and more efficient proposal.

${ }^{88}$ The economic reasoning is the same as discussed supra note 72 . 
ing liability in this way would also exculpate the manufacturer for making a rational choice under conditions not of its own choosing. ${ }^{87}$

\section{B. When to Hold a Coercing Dealer Liable}

\section{Holding the Coercing Dealer Solely Liable}

In the coerced manufacturer example, the coercing dealer is truly the culpable party. It is the party who issues the ultimatum and changes the manufacturer's business position. Because of the coercing dealer's actions, the manufacturer is forced to choose one dealer and limit its (the manufacturer's) marketing strategy. But the pending legislation would render both the manufacturer and the coercing dealer per se liable for damages, and the law under Business Electronics renders them both liable subject to a rule of reason analysis.

As discussed, the manufacturer's preference for the full-price dealer over the discounter should not be considered undesirable, since the manufacturer will probably choose the more productive dealer. It is that the manufacturer must make the choice at all that is undesirable. To try to attack this problem at the source, we need a solution that directly deters the coercion. Such direct deterrence would be embodied in a rule that holds only the coercing dealer liable for its coercive behavior. This rule would have the following effects: first, the coercing dealer would carry the full weight of the liability, and as a result, its coercive behavior would be reduced to a greater extent than under a rule where the dealer shares liability with the manufacturer. ${ }^{88}$ Second, the manufacturer will not be held liable for making a rational procom-

${ }^{87}$ The rationale is akin to that of duress in criminal law. "The rationale of the defense of duress is that, for reasons of social policy, it is better that the defendant, faced with the choice of evils, choose to do the lesser evil . . . in order to avoid the greater evil threatened by the other person." W. Lafave \& A. ScotT, Substantive CRIMINal LAw $\S 5.3$ (1986). In antitrust law, the "evil" of a restraint of trade is its effect on competition, primarily interbrand competition. Cf. Continental T.V., Inc. v. GTE Sylvania Inc., 433 U.S. 36, $52 \mathrm{n.19}$ (1977) ("Interbrand competition . . . is the primary concern of antitrust law."). With regard to the coerced termination decision, the manufacturer is faced with a choice between two "evils"; no matter which dealer it chooses to have continue selling its product, the manufacturer's interbrand competitiveness will be decreased. Exculpating the manufacturer for choosing the full-price dealer permits the manufacturer the unfettered freedom to choose the dealer who will be the better interbrand competitor. See supra notes 76-86 and accompanying text. The manufacturer's choice will not necessarily be based on efficiency, but rather on size. The manufacturer would wish to retain the distributor who could sell more of its widgets. Of course, as will be discussed in Part IV, the optimal result would be for the manufacturer not to have to make the choice to begin with. It would be better to hold the fullprice dealer solely liable for forcing the choice on the manufacturer.

${ }_{88}$ The economic reasoning is similar to that discussed supra note 72 . 
petitive business judgment when given an ultimatum..$^{89}$

Such a rule, however, would not be within the scope of section 1 , for we would be holding the dealer solely liable for its act of coercion; the cause of action would not be for a contract, combination, or conspiracy in restraint of trade, but for a unilateral anticompetitive act. The act creating liability would be the coercion, not the termination. The coercion results in the termination which in turn results in damages, but the termination itself is not what would be actionable under this rule. ${ }^{90}$

\section{The Distinction between "Acceptable" and "Unacceptable"} Coercion

Let us revisit the example described in the Introduction. ${ }^{91}$ Suppose the full-price dealer delivers the ultimatum to the manufacturer because it is no longer profitable enough for it to sell the manufacturer's widgets; the full-price dealer's conduct is the result of higher opportunity costs. ${ }^{92}$ Should such coercion be deemed illegal? While it is true that the full-price dealer gives the manufacturer an ultimatum, the fullprice dealer is acting as a rational economic actor in deciding that quitting would be preferable to remaining in competition with the discounter. It may be true that the manufacturer would like to keep both dealers, ${ }^{93}$ but the ultimatum is simply a way for the full-price dealer to communicate to the manufacturer that such a marketing strategy is not

s9 See supra note 87.

90 A plaintiff alleging a violation under such a rule would probably also be alleging a section 1 violation. If the section 1 violation fails, then the plaintiff would fall back on a claim based on the full-price dealer's act of coercion. See infra Part IV.

91 See supra notes 1-4 and accompanying text.

92 "Opportunity cost" is "[t]he cost of using resources for a certain purpose, measured by the benefit or revenues given up by not using them in their best alternative use." R. Lipsey \& P. Steiner, Economics 952 (6th ed. 1981) (definition from glossary). In our example, the full-price dealer's opportunity cost of continuing to sell the manufacturer's widgets would be the profits that it could make if the full-price dealer were to put its resources to their best alternative use (e.g. selling a different manufacturer's widgets or getting into an entirely different line of business).

93 The manufacturer might want to capture different segments of the market:

For some consumers, the knowledge that they are purchasing from a retail store which offers related sales services and which is associated with a developed goodwill and reputation spells reliability as to that retail store and the products sold therein. But for other consumers, buying quality products at a cheaper price is the raison d'etre of a retail shopper's life. Accordingly, many manufacturers utilize "dual distribution" operations, selling both to full-price and discount retailers on the premise that they are covering the market with a multifaceted vertical marketing approach.

Calmann, Restraints Permitted in Vertical Distribution Field, N.J.L.J., Aug. 11, 1988 , at 17 , col.1. 
possible. ${ }^{94}$

This illustrates the point that not all coercive behavior by a dealer should be proscribed. The ultimatum given by the full-price dealer here is an example of what I will call "acceptable" coercion. More generally, coercion should be deemed "acceptable" if it is motivated by a superior value of the opportunity cost of selling widgets (measured by anticipated profits) as compared with the value of continuing to sell the widgets for the manufacturer in competition with the discounter. The full-price dealer is merely telling the manufacturer that it would be more profitable for it not to sell the manufacturer's widgets and allocate its resources elsewhere, than it would be to continue selling the widgets in competition with the discounter. The choice forced on the manufacturer is not the result of strategic behavior on the part of the full-price dealer, but of the exigencies of a business trying to make a normal profit. 95

With "acceptable" coercion, the dealer has nothing to lose by delivering the ultimatum..$^{96}$ If the manufacturer chooses to keep the discounter, then the full-price dealer will leave the market and allocate its resources to a more profitable endeavor; if the manufacturer terminates the discounter, then the full-price dealer will continue to sell widgets. ${ }^{97}$

94 In Monsanto, the Court discussed the need of the manufacturer to communicate with its dealers about its marketing strategy:

[D]istributors are an important source of information for manufacturers.

In order to assure an efficient distribution system, manufacturers and distributors constantly must coordinate their activities to assure that their product will reach the consumer persuasively and efficiently. To bar a manufacturer from acting solely because the information upon which it acts originated as a price complaint would create an irrational dislocation in the market.

Monsanto Co. v. Spray-Rite Serv. Corp., 465 U.S. 752, 763-64 (1984); see also Point/ Counterpoint, supra note 73, at 35 (Silberman, Counterpoint):

Sound effective manufacturer strategies require extensive two-way communication in the distribution system. . . [T] the sole source of wisdom; if the local distributor believes that the manufacturer's approach is not efficacious, the local distributor should be free to communicate those thoughts upward. More often than not, the local distributor will want to use various examples in communication -- he will refer to other companies that are his competitors.

Id. at 35 .

${ }_{95}$ "Normal Profits" is "[a] term . . . for the imputed returns to capital and risk taking just necessary to keep the owners [of a business] in the industry." R. LIPSEY \& P. STEINER, supra note 92, at 952.

${ }_{96}$ Assuming, for the moment, that there were no legal proscription.

${ }^{97}$ The natural assumption is that the value of selling widgets without the discounter in the market is greater than the value of allocating its resources elsewhere. If this were not true, then the retailer would not deliver an ultimatum; it would simply leave the market. 
By contrast, "unacceptable" coercion is coercion where the value of the full-price dealer's opportunity cost is less than the value of continuing to deal in the widgets. ${ }^{98}$ Here, the full-price dealer does have something to lose by coercing. If the manufacturer chooses the discounter over the full-price dealer and the full-price dealer carries out its threat, it would cease doing business with the manufacturer and allocate its resources elsewhere. By doing so, however, the full-price dealer is worse off than if it were to continue selling widgets in competition with the discounter.

The full-price dealer probably engages in "unacceptable" coercion because it expects the manufacturer to choose it over the discounter. The full-price dealer is acting strategically; it is taking a gamble. Perhaps it is secure in its market position; ${ }^{99}$ perhaps it is bluffing. The result, however, is coercion that should not be tolerated. Such coercion is truly anticompetitive because it is designed only to reduce intrabrand competition and to increase the full-price dealer's profits. Although with "acceptable" coercion the full-price dealer also reduces intrabrand competition and increases its profits, the results are justified; "acceptable" coercion is a legitimate mechanism by which the manufacturer is informed that its current marketing strategy cannot continue.

\section{A Proposal for a Unilateral Antitrust Offense}

\section{A. The Proposal}

This Comment proposes that Congress should not enact the pending legislation, but that the law, as it now stands after Business Electronics, should be modified to hold dealers liable who engage in "unacceptably" coercive conduct resulting in the termination of rival dealers. Since the coercing dealer would be held unilaterally liable, the proposed modification would not fit into the existing framework of a section 1 violation. The modification proposed would require either an amendment to the existing laws or new legislation.

The proposal would work as follows: When the discounter in our

${ }^{98}$ There is another type of "unacceptable" coercion. This would be where the full-price dealer engages in coercive conduct that does not amount to a threat to cease doing business, but rather is behavior that puts the manufacturer's product in a less favorable light so as to put pressure on the manufacturer to terminate the discounter. See, e.g., Garment Dist., Inc. v. Belk Stores Servs., Inc., 799 F.2d 905, 907 (4th Cir. 1986) (full-price dealer excluded manufacturer from its annual trade show and put manufacturer's goods in its "budget basement" to pressure manufacturer into terminating a discounter), cert. denied, 108 S. Ct. 1728 (1988).

o9 See supra note 10 . 
example $\mathrm{e}^{\mathbf{1 0 0}}$ is terminated subsequent to communications between the full-price rival and the manufacturer, the first line of inquiry for the jury to answer would be whether or not there was a price fixing agreement between the manufacturer and the full-price dealer. If there was, then that agreement would be per se illegal under Business Electronics, and both the full-price dealer and the manufacturer would be subject to liability. ${ }^{101}$

If no price fixing agreement is found, then the next line of inquiry would be whether or not the full-price dealer engaged in coercive conduct. ${ }^{102}$ If it did not, then we would ask if the manufacturer's decision was unilateral. If unilateral, then under the Colgate doctrine the termination would be per se legal; if the termination was not unilateral (and thus pursuant to an agreement with the full price dealer), then the termination would be examined under the rule of reason. ${ }^{103}$

If the full-price dealer engaged in coercive conduct, then we would ask if the coercion was "acceptable."

100 See supra notes $1-4$ and accompanying text.

102 It may seem inconsistent for this Comment to argue that both the manufacturer and full-price dealer should be held liable for vertical price and non-price restraints, but that the full-price dealer alone be held liable for a coerced termination. The argument that the manufacturer, in imposing such restraints, is acting competitively (even if the competing dealers who participate in the imposition of such restraints are acting anti-competitively) is as applicable to vertical price and non-price restraints as it is to coerced terminations. See, e.g., R. BoRK, supra note 80, at 297 (arguing that "all vertical restraints are beneficial to consumers and should for that reason be completely lawful"); R. POSNER, supra note 2, at 147-67 (arguing against per se illegality of resale price maintenance); Baxter, supra note 18, at 946 (arguing that manufacturer imposed resale price maintenance is beneficial to consumers); Piriano, The Case for Presuming the Legality of Quality Motivated Restrictions on Distribution, 63 NoTRE DAME L. REV. 1, 4 (in cases where "the courts can be reasonably certain of a manufacturer's procompetitive motives, all vertical restrictions . . . should be afforded a presumption of legality.").

Since it is unlikely that Congress would soon exculpate manufacturers from liability for most vertical restraints, see Piriano, supra, at 34, this Comment carves out an exception to the general rule of joint liability. Since the full-price dealer is the truly culpable party in the coerced termination, it is logical that the full-price dealer alone be held liable.

102 The conduct would have to be sufficiently coercive that the fact finder could reasonably conclude that the manufacturer's decision was coerced. For example, an ultimatum might be considered more coercive than a mere complaint. For a general discussion on proving coercion of a manufacturer see 7 P. AREEDA, supra note 10, at para. $1457 \mathrm{c}$.

${ }^{103}$ Since no price agreement had been found, then this would be a vertical nonprice restraint. See supra notes $20-24$ and accompanying text. The rationale for retaining joint liability for vertical non-price restraints is the same as that discussed in the context of vertical price restraints, see supra note 101.

104 The evidence used to prove or disprove acceptable coercion would probably try to establish and compare the full-price dealer's profits at the time of the coercion, and the full-price dealer's opportunity costs, see supra note 92, at that time. Such evidence would probably be similar to that used in law suits where a corporation's profits, po- 
would be imposed on anyone; if the coercion was "unacceptable," then liability would be imposed on the full-price dealer alone.

\section{B. Manufacturer's Motive For Terminating Not Decisive}

It is possible for the manufacturer to make a unilateral decision even though the full-price dealer engages in coercive conduct. ${ }^{105}$ Should the full-price dealer then be permitted to plead as an affirmative defense that the manufacturer's termination decision was unilateral and therefore valid under the Colgate Doctrine? If so, then even if the jury were to find that the coercion was "unacceptable," it would not be held liable if it was proved that the manufacturer made the decision unilaterally.

This defense carries with it two major problems. First is the issue of whether or not juries can adequately determine a manufacturer's motivation for terminating. ${ }^{106}$ Second is the incentive for the manufacturer to claim that its decision was unilateral action even if in reality it was coerced. For instance, if the full-price dealer continued to have a business relationship with the manufacturer at the time of discovery in an action against the full-price dealer, then the manufacturer would have a very strong motivation to claim that its decision to terminate was unilateral. Furthermore, if the action is brought under both section 1 and under this proposal, then the manufacturer might plead unilateral action in an attempt to minimize its exposure to liability. If the Business Electronics majority is correct about the juries' abilities, ${ }^{107}$ then making the manufacturer's decision relevant would render this proposal ineffective. Once a defendant full-price dealer claims as an affirmative defense that the manufacturer's decision was unilateral, then the jury would not be permitted to determine the case on its merits.

Such an affirmative defense should not be allowed under this proposal. I will not rest the conclusion to disallow for such an affirmative defense on the difficulty of determining the manufacturer's motivation, but rather on the notion that "unacceptable" coercion should be deterred. Naturally, if the manufacturer were to choose not to terminate under dealer pressure, then there would be no cause of action. But, in

tential profits, or future earnings are at issue.

${ }_{108}$ The action that the full-price dealer is trying to elicit from the manufacturer is an action that the manufacturer would take regardless of the threat. A simple example will illustrate: $\mathrm{X}$ says to $\mathrm{Y}$ : "Either continue to breathe or I will kill you!" $\mathrm{Y}$ continues to breath, regardless of the threat on his life. $\mathrm{X}$ engaged in coercive conduct, but $\mathrm{Y}$ 's breathing was independent of the threat.

${ }_{108}$ See supra text accompanying note 50.

107 See id. 
any instance where a discounter is terminated following "unacceptable" coercion, this would be sufficient to give rise to an irrebuttable presumption that the discounter was terminated in response to the coercion, making the coercer liable. The manufacturer's true motivation for terminating should be deemed irrelevant as being of no probative value in determining whether or not the coercive behavior was "acceptable."

\section{CONCLUSION}

The legality of vertical restraints of trade is examined within the section 1 framework. Section 1 requires that the restraint be the product of concerted action; in dealer termination cases, therefore, the fullprice dealer and the manufacturer will either both be subject to, or exempt from, liability. Coerced terminations, however, differ from restraints that are the product of genuine agreements. A dealer engages in "unacceptable" coercion to increase an already profitable business at the expense of both another dealer and consumer welfare. The coercing dealer should be subject to liability for such coercion. The coerced manufacturer, however, does not act anticompetitively when it decides to terminate a dealer in the face of coercion. The manufacturer would prefer to keep both distributors, but the ultimatum forces it to limit its distribution; the manufacturer will choose the better interbrand competitor, which may mean responding to the ultimatum by terminating the rival dealer.

It is not the termination decision that is anticompetitive, but rather the coercion that imposes the decision on the manufacturer that is anticompetitive. If the termination is viewed as the restraint, then indeed, there is concerted activity; but if the coercion is viewed as the restraint, then there is unilateral anticompetitive conduct. Considering the coercion, rather than the termination, to be the restraint of trade is a novel approach to an old problem. The manufacturer is exculpated for making a procompetitive business judgment, and the full-price dealer is held liable for forcing an anticompetitive decision on the manufacturer. 